\title{
FOLLOWING DIOXIN'S DRIFT: AGENT ORANGE STORIES AND THE CHALLENGE OF METABOLIC HISTORY
}

DAVID BIGGS

\section{Abstract}

This essay addresses a more global history of dioxin's drift via the herbicide 2,4,5-T, better known in Vietnam as the dioxin-tainted herbicide in Agent Orange, but also widely available as a commercial herbicide. Drawing on theories of metabolic flow that challenge Marxist and other notions of a social-nature divide, the essay uses 2,4,5-T and dioxin as a focus for writing a metabolic history to examine how the origins, delivery and fate of a herbicide can pass far beyond expected boundaries. It uses the concept of drift with respect to the herbicide and its contaminant to get at a core challenge facing writers in environmental history and the environmental humanities: how to describe environmental phenomena with multiple and often divergent cascades of causal effects in different social, economic and ecological settings. A focus on a toxic molecule's drift through multiple metabolic webs challenges readers to think beyond dominant moral frameworks and re-orient themselves to a more dynamic, multi-threaded approach.

Keywords: Agent Orange, Vietnam, dioxin, metabolic history, toxic chemicals

\section{Introduction}

On the morning of 21 January 1970 in central Vietnam, helicopter pilots with the 10th Chemical Platoon commenced aerial spraying around a hilltop with a mixture of the tactical herbicide Agent Orange (350 US gallons (1,325 L)) and diesel (200 US gallons (757 L)). Using a UH-1 'Huey' helicopter with a spray rig, the pilots made five trips from their helipad at Camp Eagle to Firebase Bastogne on a hilltop near the A Sầu Valley and Laos (see Figure 2). Their 'defol' (defoliation) mission was to clear vegetation to reduce cover from snipers who might hide in the surrounding forest. Defoliation, however, was just one of the 10th Chemical's missions that day. In the afternoon, they loaded a CH-47 'Chinook' helicopter with drums of napalm for a 'bulk flame drop'. The platoon strapped a dozen drums together (660 US gallons $(2,498 \mathrm{~L}))$, then released them several thousand feet above 
the target. As the drums fell to the ground, a fighter jet swooped in and strafed them with bullets to create a giant fireball that burned the ground and incinerated or suffocated anyone hiding below. The 10th Chemical ran 11 'bulk flame drops' that afternoon over a coastal area of marshes and dunes where the US 101st Airborne's 3rd Brigade was fighting. After these missions concluded at $3.30 \mathrm{pm}$, the 10 th Chemical Platoon ran one final operation at $5 \mathrm{pm}$, a 'sniffer mission'. The 'sniffer' crew piloted a 'Huey' fitted with a high-tech ammonia-sniffing device. They flew 'low and slow', just above the treetops, to record minute traces of ammonia in the air. For each ammonia trace detected, they recorded map coordinates, setting future targets for bombing. ${ }^{1}$

This one-day snapshot of the 10th Platoon's operations suggests the complex web of chemical activities involved in an average day for one army unit in the Vietnam War. While Agent Orange-related stories about the herbicide and its contaminant 2,3,7,8-TCDD (dioxin) have become synonymous with the Vietnam War, the broader chemical, political and ecological context of the herbicide's use in Vietnam is forgotten. ${ }^{2}$ Also forgotten by many today is the commercial context from which Agent Orange was 'born'. Despite its strange name, the herbicide was not a special military weapon so much as a military-formulated herbicide cocktail developed from two of the most popular commercial herbicides on the market in the 1950s (2,4,5-T and 2,4-D). Before, during and after the US military's use of Agent Orange in Vietnam, the same herbicide tainted by the same dioxin was available at neighbourhood hardware stores from 1948 until a total ban in $1985 .^{3}$ Most of

1 These missions are detailed in the 10th Chemical Platoon's Daily Mission Log: Chemical Officer Daily Journal, Box 1, 101st Airborne Division, United States Army Vietnam, Record Group 472, National Archives and Records Administration-College Park (NARA2). As with most US military operations, there were manuals that explained procedures for each of these chemical operations. For the manual used by the 10th Platoon, see Box 1, 10th Chemical Platoon, Chemical Units, RG 472, NARA2.

2 There is an extensive historiography dedicated specifically to the tactical herbicide program and studies of Agent Orange. For a detailed account of the legal and scientific controversies surrounding Agent Orange, see Edwin Martini, Agent Orange: History, Science and the Politics of Uncertainty (Amherst, MA: University of Massachusetts Press, 2012). David Zierler explores internal American government and public responses to legal and diplomatic concerns over tactical herbicides, especially whether they could be considered as a chemical weapon. See Zierler, The Invention of Ecocide: Agent Orange, Vietnam, and the Scientists Who Changed the Way We Think About The Environment (Athens, GA: University of Georgia Press, 2010). Former US Air Force chemist and herbicide researcher Alvin Young has produced one of the most comprehensive inside Department of Defense (DOD) perspectives in The History, Use, Disposition and Environmental Fate of Agent Orange (New York: Springer, 2009). In the arena of public health, Drs Jeanne and Steven Stellman at Columbia University's Mailman School of Public Health have for more than 30 years been at the centre of scientific and Congressional debates over US veteran exposure. For one of their most-cited essays, see Jeanne Mager Stellman, Steven D. Stellman, Richard Christian, Tracy Weber and Carrie Tomasallo, 'The extent and patterns of usage of Agent Orange and other herbicides in Vietnam', Nature 422 (2003): 681-7, doi.org/10.1038/nature01537.

3 Agent Orange was a military herbicide formulated from two widely used commercial herbicides, 2,4-D and 2,4,5-T, beginning in 1963. 2,4,5-T is short for 2,4,5-Trichlorophenoxyacetic acid and, like 2,4-D, is a synthetic organic herbicide developed from naphthenic acid that acts as a synthetic plant growth hormone. The US military developed three precursors in 1962-65 also based on 2,4,5-T: Agents Green, Pink and Purple; however, Agent Orange replaced these earlier herbicides by 1965. For more details, see Young, The History, Use, Disposition and Environmental Fate of Agent Orange, 5. 
the court cases, settlements, histories and narrative works on Agent Orange barely acknowledge this commercial web where 2,4,5-T and dioxin travelled to millions of acres of backyards, golf courses, roadsides, ponds, forests and pastures in the US, other developed countries and even the Soviet Union.

This contrast between dioxin's different 'drifts' through US chemical war actions in Vietnam and commercial herbicide use globally stems from not only the very different legal bases of its production but also the political and metabolic terms of its distribution. In the case of Agent Orange, mounting political opposition to the Vietnam War and a wave of veterans' and Vietnamese claims set into motion a persistent, concentrated public focus on Agent Orange amid charges of a new war crime termed 'ecocide' for the US military's intentional destruction of ecosystems and food crops. Since the war's end in 1975, decades of litigation, Congressional hearings and scientific studies have failed to fully resolve scientific questions on dioxin's links to particular diseases, in what the historian Edwin A. Martini terms a 'politics of uncertainty'. The unique terms of Agent Orange's formulation, distribution and chemical 'fate'-its metabolic flows from aircraft to specific bodies and ecosystems have in turn produced chemical histories with specific Vietnamese, American, Korean and other state-centred variants. ${ }^{5}$ The US Congress passed an Agent Orange Act in 1991 to fund more research, thus adding money and the legal presumption of American veteran exposure (not extended to Vietnamese or non-US claimants). ${ }^{6}$ By contrast, the metabolic-economic webs through which commercial 2,4,5-T and its dioxin drifted were globally dispersed. What of individualspesticide applicators, home gardeners, landscaping crews - exposed to dioxin's drift through commercial channels? The spatial and historical limits of the Agent Orange story and repeated administrative failures to serve all groups claiming exposure to dioxin via Agent Orange obscure a potentially much wider population of people exposed to 2,4,5-T. The failure of societies to address the total spread of dioxin through all of these webs of production and transport constitutes a form of what the literary scholar Rob Nixon calls 'slow violence', as illnesses tend to manifest over

\footnotetext{
4 Martini, Agent Orange, 158-9.

5 As with histories of Agent Orange, there is wide spectrum of anthropological and artistic works focused on victims of exposure, too. Diane Niblack Fox's research with Vietnamese families represents years of oral history research. See Diane Niblack Fox, 'One significant ghost: Agent Orange narratives of trauma, survival, and responsibility' (PhD diss., University of Washington, 2007). Along the same lines, the anthropologist Tak Uesugi contrasts American veteran and Vietnamese perceptions of illness and exposure. See Tak Uesugi, 'Toxic Epidemics: Agent Orange Sickness in Vietnam and the United States', Medical Anthropology 35, no. 6 (2016): 464-76, doi.org/10.1080/01459740.2015.1089438. Literary and artistic representations of exposure were a core feature of a conference organised at the University of California at Riverside in May 2009, titled 'Agent Orange: Landscape, Body, Image'. Among works featured were the studies of the Japanese photojournalist Goro Nakamura. See Goro Nakamura, Agent Orange in the Vietnam War (Tokyo: Iwanami, 1981). See also Philip Jones Griffiths, Agent Orange: Collateral Damage in Vietnam (New York: Trolley, 2004).

6 A full description of associated illnesses as well as background on the 1991 Act can be found at US Veterans Affairs Administration, 'Veterans' Diseases Associated with Agent Orange', www.publichealth.va.gov/exposures/ agentorange/conditions/index.asp, accessed 19 June 2017.
} 
decades, wreaking physical and economic damage. Nixon writes about the 'contest over the administration of difference between those who gain official recognition as sufferers and those dismissed as non-sufferers because their narratives of injury are deemed to fail the prevailing politico-scientific logic of causation?.?

This essay addresses this disparity between the military and commercial origins of dioxin in 2,4,5-T by charting dioxin's global drift across the war/commerce divide, from its origins in commercial herbicide production to its specialised delivery in a Vietnamese war zone and finally to its post-war presences in bodies and ecosystems. As the historian Edmund Russell notes in his history of overlaps in military and commercial development of pesticides in the twentieth century, this essay challenges the assumption that dioxin exposure via Agent Orange was a toxic side effect of war only. Like many chemicals invented in the 1940s, it repeatedly crossed the militarycommercial divide. ${ }^{8}$ In addressing dioxin's more global drift, I employ the notion of metabolism or metabolic flows as metaphor, a metabolic history approach to a chemical, dioxin, that passes through multiple spatial and temporal scales and works simultaneously in the realms of ecology, politics, economics and even genetics. Like many environmental actors, dioxin figures into physical metabolic processes at the same time that it figures into social or political ones, such as calculations of payouts to Vietnam veterans. Such environmental stories with non-human actors tied to inter-related causes and effects often lack central subjects (perpetrators, decisionmakers and victims) and, as a consequence, they may appear to lack a compelling moral framework. This lack of a moral framework in environmental stories, and drift as an alternative to intentionality, present central problems to historians and all who work with narrative forms. In an essay explaining the limited response of fiction writers to climate change, Amitav Ghosh suggests that one reason for the aversion to such complex, 'metabolic' stories stems from this problem for writers and politicians alike; experiences of complex, slow-acting phenomena do not equate to the kinds of 'individual moral adventures' easily understood in stories. He writes: 'As for the nonhuman, it is almost by definition excluded from a politics that

\footnotetext{
7 Rob Nixon, Slow Violence and the Environmentalism of the Poor (Cambridge, MA: Harvard University Press, 2011), 47. One example of a literary work in this vein is the influential 1983 account of US veterans' struggles with illnesses associated with exposure in Vietnam by Fred A. Wilcox, Waiting for an Army to Die: The Tragedy of Agent Orange (New York: Seven Stories Press, 1983).

8 Lesa L. Aylward and Sean M. Hays, 'Temporal trends in human TCDD body burden: Decreases over three decades and implications for exposure levels', Journal of Exposure Science and Environmental Epidemiology 12 (2002): 319-28, doi.org/10.1038/sj.jea.7500233. Russell pays close attention to the insecticide DDT, among other pesticides; the case of 2,4,5-T and the 'tactical' herbicides is somewhat unique in that the DOD sought new formulations and new modes of using the herbicide that differed from commercial uses. Even in war zones such as Vietnam, the DOD used DDT and other pesticides in the same prescribed ways and for the same purposes as pesticide applicators in the United States. See Edmund Russell, War and Nature: Fighting Humans and Insects with Chemicals from World War I to Silent Spring (Cambridge: Cambridge University Press, 2001).
} 
sanctifies subjectivity. . Atmospheric carbon dioxide, like drifting dioxin molecules, lacks subjectivity unless it can be coupled to an individual moral framework with human perpetrators and victims such as with 'ecocide' in Vietnam.

This metabolic challenge, framing environmentally complex stories in broader moral or eco-political frameworks that reflect evolving metabolic relationships at multiple scales, is important to writers and readers alike as they struggle to conceive of new meaning for lives and communities deeply connected through food, movement and health to planetary ebbs and flows across multiple scales from planetary systems to proteins in one's DNA. How might historians recast past events and individual decisions in metabolic terms? How does one argue causation or select 'followable' subjects in such an interconnected, multi-scalar setting? Ghosh suggests that this challenge faces fiction writers who seek literary means to respond to such impending problems as climate change. ${ }^{10}$ In her innovative study of the history of endocrine disruptors, the historian Nancy Langston gets at this problem as it faces historians. She describes failures in government regulation of endocrine-disrupting chemicals as 'metabolic failures'. She writes: 'Failures of regulation are expressed not just in hearings and court cases, but also inside our own bodies'. ${ }^{11}$ She challenges readers throughout her work to recast the history of endocrine-disrupting chemicals in both a more global, and a more embodied, metabolic framework.

This essay answers this challenge by focusing on the herbicide 2,4,5-T, its dioxin and drift of the herbicide, and the dioxin as a metaphor for framing new stories about complex environmental, social and metabolic exchanges. By following drift, one can travel along disparate webs of social, political and physical factors playing into the initial commercial production or 'birth' of the herbicide, the political and ecological effects of its 'delivery' to mass markets and Vietnamese ecosystems, and the political and genetic stories associated with its degradation, half-life, 'death' and 'afterlife'. While such a metabolic or web-of-life approach may not be common, there are nonetheless literary and historiographical traditions that inform it. Rachel Carson's popular reception in the 1950s and 1960s stemmed from her ability to eloquently link human bodies to what she called 'the web of life' in water, air and micro-organisms crossing terrestrial, aquatic and bodily domains. One of her first bestsellers, The Sea Around Us, took readers from the shores of Chesapeake Bay to exotic, aquatic realms; her final book, Silent Spring, took a similar approach but

9 Amitav Ghosh, The Great Derangement: Climate Change and the Unthinkable (Chicago: University of Chicago Press, 2016), 129.

10 There are, as Ghosh is quick to note, many literary exceptions. One notable literary exception in non-fiction who is particularly fascinated with the idea of drift is Donovan Hohn, Moby-Duck: The True Story of 28,800 Bath Toys Lost at Sea and of the Beachcombers, Oceanographers, Environmentalists and Fools, Including the Author Who Went in Search of Them (New York: Penguin, 2012).

11 Nancy Langston, Toxic Bodies: Hormone Disruptors and the Legacy of DES (New Haven, CT: Yale University Press, 2011), xiii. 
used the interconnectivity of these worlds to show how vulnerable humans were to new forms of industrial pollution. Carson squared her metabolic approach with America's post-war chemical industries, writing:

For each of us, as for the robin in Michigan or the salmon in the Miramichi, this is a problem of ecology, of interrelationships, of interdependence. We poison the caddis flies in a stream and the salmon runs dwindle and die. We poison the gnats in a lake and the poison travels from link to link of the food chain and soon the birds of the lake margins become its victims ... These are matters of record, observable, part of the visible world around us. They reflect the web of life — and death — that scientists know as ecology. ${ }^{12}$

Carson popularised this web-of-life approach by drawing heavily on several decades of biological and ecological writing, and politicians as well as reading publics responded. ${ }^{13}$ More recently, scholars in the social sciences have advanced a similar web-of-life approach to re-evaluate even the more traditionally human domains of technology, cities and trade. Bruno Latour in We Have Never Been Modern critiques humanist scholarship that evaluates modern society separately from nature, making a case for nature-society hybridity and agency via actor networks. ${ }^{14}$ The geographer Erik Swyngedouw takes a similarly hybrid approach to cities, considering built environments such as urban water supply systems as the result of 'a particular sociospatial process of metabolizing nature, of urbanizing the environment'. ${ }^{15}$ More recently, the sociologist Jason Moore has advanced a world-systems analysis of Karl Marx's concept of the metabolic rift in Capital, diverging from other scholars of ecological Marxism to suggest that historical capitalism does not produce just ecological crises but that ecological crises in turn produce new forms of capital relations. ${ }^{16}$ Carson's more poetic descriptions of the 'web of life' have thus given way to a broad environmental turn in the social sciences and humanities that encompasses metabolic exchanges in myriad ways.

At specific points in the following sections and in several different ways, this metabolic history of 2,4,5-T and dioxin points to these well-established metabolic approaches as they relate to different scales and realms (economic, political, technological) of

12 Rachel Carson, Silent Spring (Boston, MA: Houghton Mifflin, 1989), 189.

13 There is an extensive literature in the history of these ideas. Donald Worster is one of the first historians to have tackled ecological ideas, compiling several comprehensive surveys of Western environmental thought. See Donald Worster, Nature's Economy: A History of Ecological Ideas (Cambridge: Cambridge University Press, 1977); and Donald Worster, The Wealth of Nature: Environmental History and the Ecological Imagination (New York: Oxford University Press, 1994).

14 Bruno Latour, We Have Never Been Modern (Cambridge, MA: Harvard University Press, 1991).

15 Erik Swyngedouw, Social Power and the Urbanization of Water: Flows of Power (New York: Oxford University Press, 2004), 8.

16 Jason W. Moore, 'Transcending the metabolic rift: A theory of crises in the capitalist world-ecology', Journal of Peasant Studies 38, no. 1 (2011): 11. Moore is responding in particular to earlier interpretations of Marx's idea of the metabolic rift that see the relationship of modern economies as one-way, in effect producing impacts or footprints. See John Foster, Marx's Ecology: Materialism and Nature (New York: Monthly Review Press, 2000); also see Karl Marx, Capital (New York: Vintage, 1981), 3: 949. 
dioxin's drift. Moore's works returning to Marx's initial interest in the 'rift' between capitalist social processes and ecological crises have in particular ignited new debates among sociologists as Moore, like Latour, disputes the assumed divide between social and natural systems. ${ }^{17}$ This essay borrows from Moore, Latour and other sociologists, challenging the nature-culture divide, but it also focuses in particular on the concept of 'drift' as a way to follow 2,4,5-T and its dioxin as it travels through these 'rifts' with some degree of agency but no intent. The term 'drift' is a technical term often used in the toxicology of pesticides, but in this essay it serves more metaphorically for a synthetic organic agent that circulates but lacks subjectivity or even direction. The term 'metabolic', too, has many different technical meanings depending on discipline and context. In this essay, I use it generally to describe processes that are both socially and physically defined or catalytic. The herbicides 2,4,5-T and TCDD dioxin as compounds are not just symbolically or legally metabolic, but, like Langston's endocrine disruptors, they are physically metabolic agents acting on plant growth, organism cell function and DNA imprinting.

The following sections are organised into a three-stop tour that follows the herbicide and its contaminant from its origins/birth to its travels/life and finally its fate/death and afterlife. It begins with 2,4,5-T's origins in the coal-tar chemicals naphthalene and benzene, products born squarely out of what the political theorist Timothy Mitchell describes as a 'carbon democracy' built around multinational corporations, military-industrial relationships and fossil fuels. ${ }^{18}$ This first stop explores the 'birth' of 2,4,5-T as an 'economic poison' in both commercial and military webs. A short section follows this with the logic that drove the US in 1959-60 to send it to Vietnam. ${ }^{19}$ The second section considers the metabolic shifts associated with 2,4,5-T's delivery into war zones in Vietnam. The herbicide 2,4,5-T moved through terrains from military bases to mountain jungles that were subject to systematic destruction. Unimaginable amounts of explosives, incendiaries (napalm) and herbicides were used to render many forest and rural ecosystems into abiotic surfaces. The third section considers the post-war interfaces where dioxin's drift by the 1990s figured as a toxic residue in Vietnamese bodies, community politics and international debates. The conclusion considers how these metabolic exchanges and metabolic histories often run up against challenges presented by more ethically or morally framed Agent Orange stories.

17 Jason W. Moore, 'The End of the Road? Agricultural Revolutions in the Capitalist World-Ecology, 14502010', Journal of Agrarian Change 10, no. 3 (2010): 389-413, doi.org/10.1111/j.1471-0366.2010.00276.x.

18 Timothy Mitchell, Carbon Democracy: Political Power in the Age of Oil (New York: Verso, 2011).

19 As of 1947, the Federal Insecticide, Fungicide, and Rodenticide Act (FIFRA) defined all pesticides, including herbicides, as 'economic poisons', meaning substances intended to destroy or prevent any insect, rodent, fungus, weed, virus or other form of plant and animal life designated by the Secretary of Agriculture as a pest. Defoliants, especially synthetic auxins such as 2,4,5-T, were specifically added to this list with the 7 August 1959 Amendment to FIFRA. See United States Environmental Protection Agency, Legal Compilation: Statutes and Legislative History, Executive Orders, Regulations, Guidelines and Reports (Washington, DC: GPO, 1973), 47, 89. 


\section{Synthetic origins}

The herbicide 2,4,5-T was not so much born out of military-industrial relations in the Second World War as an earlier wave of military-industrial activity in the First World War. Coal tar was the first source of many new synthetic organic chemicals such as TNT (trinitrotoluene) and various benzenes. In his 1917 book, The Treasures of Coal Tar, the Welsh chemist Alexander Findlay tied the future of Britain's textile industries and its war effort to coal tar. ${ }^{20}$ During the First World War, scientists and chemical companies used coal-tar distillates such as naphthalene and benzene to produce a wide array of dyes, solvents, explosives, resins, photographic chemicals, medicines and flavours. Military and industry ties that began around coal tar expanded with the development of petroleum distillates in the $1930 \mathrm{~s} .{ }^{21}$ As internal combustion engines in the 1920s drove a shift in global demand from low-sulphur coal to light sweet crude, scientists explored potential applications for a wider array of petrochemicals derived from coal and then petroleum production.

Within these established petrofuel networks, plant researchers in the 1920s focused on naphthenic acid and chemicals derived from it, including 2,4-D and 2,4,5-T as mimics of the plant growth hormone auxin. The historian Nicolas Rasmussen notes that for almost a decade none of the scientists exploring synthetic auxins had considered that overstimulation of a plant's metabolic functions could kill it. One of the leading scientists in this research, Ezra Kraus, was among the first to make that jump while the United States ramped up its war efforts in 1942, suggesting that the US military could use 'hormone overdoses as herbicides' to destroy Japanese rice crops and jungles covering Japanese-held Pacific islands. ${ }^{22}$

Considering Moore's ecological view of capitalism and its transcendence of 'metabolic rifts', this was the sort of invention that allowed a 'cheap fix' to achieve savings in labour and money. The combined economic and ecological 'work' done by $2,4,5-\mathrm{T}$, replacing human labourers in agriculture, promised to transform one key economic aspect of the traditional farm economy-replacing permanent or temporary farmhands and expensive machines. As the United States expanded its war in the Pacific, Kraus argued for herbicides as a form of 'cheap nature' in the military economy; it could be an inexpensive way to quickly destroy vegetation

20 Alexander Findlay, The Treasures of Coal Tar (New York: D. Van Nostrand Co., 1917), 122-30.

21 Benjamin T. Brooks, 'Synthetic Organic Chemicals from Petroleum: An American Development', Industrial and Engineering Chemistry 31, no. 5 (1939): 515-19, doi.org/10.1021/ie50353a006.

22 Nicolas Rasmussen, 'Plant Hormones in War and Peace: Science, Industry, and Government in the Development of Herbicides in 1940s America', Isis 92, no. 2 (2001): 302, doi.org/10.1086/385183. 
cover on Pacific islands, in turn saving soldiers' lives. ${ }^{23}$ Despite several years of testing, however, the military did not implement the herbicide program before the war ended.

When the Pacific war ended in 1945, scientists and chemical company executives scrambled to bring new chemicals, especially pesticides, to commercial markets. The commodification of 2,4,5-T began when a competitor to Kraus filed a patent application for 27 formulations of herbicides, including every imaginable formulation for 2,4-D and 2,4,5-T herbicides. His preferred herbicide was a 50/50 mixture of the two in normal butyl ester formulations, a recipe almost identical to Agent Orange and suitable, he claimed, for knocking out the poison ivy that caused his children severe allergic reactions. ${ }^{24}$ Second, because this product was potentially toxic, it required federal registration along with a host of new 'economic poisons'. The US Congress passed the Federal Insecticide, Fungicide, and Rodenticide Act (FIFRA) in 1947 to govern commercial sales of all old and new pesticides. The law designated the US Department of Agriculture (USDA) as the sole authority for regulating and registering pesticides, certifying them at its Beltsville laboratory in Maryland, and issuing guidelines for pesticide disposal. The USDA registered 2,4,5-T for commercial sale in $1948 .{ }^{25}$ The final step in the commercial proliferation was the herbicide's manufacture by chemical companies and its uptake by farmers, public works agencies and gardeners who witnessed how these 'revolutionary' chemicals did, as advertised, kill weeds so effectively, saving significant amounts of labour and money.

Over the next two decades to $1968,2,4,5-\mathrm{T}$ and other pesticides radically and globally transformed agroecologies. The commercial web of pesticide manufacturers, state and federal regulators, universities, agricultural extension offices and end users contributed to this shift, too. University research programs and crop development often followed the pesticides. While Agent Orange activists often point to the unusual, military 'birth' of 2,4,5-T in the $1940 \mathrm{~s}$, they often omit the fact that it was largely because of 2,4,5-T's commercial popularity that US Army researchers selected it for use in Vietnam. In 1958, 2,4-D and 2,4,5-T herbicides accounted for the majority of all synthetic herbicides produced and consumed in the United States. Of 40.7 million pounds ( 18.5 million $\mathrm{kg}$ ) produced in the United States in 1958, 2,4-D made up 24.9 million (11.3 million $\mathrm{kg}$ ) (61 per cent) while 2,4,5-T comprised 5.2 million ( 2.4 million $\mathrm{kg}$ ) (13 per cent). The two herbicides that later

23 In his 2015 book, Capitalism in the Web of Life: Ecology and the Accumulation of Capital, Moore outlines what seems a key role for ecology in the development of capitalist economies. He writes that capital development not only rests on accumulation and revolutions in commodity production, it also 'must ceaselessly search for, and find ways to produce, Cheap Natures'. See Jason Moore, Capitalism in the Web of Life: Ecology and the Accumulation of Capital (New York: Verso, 2015), 53.

24 Franklin D. Jones, U.S. Patent No. 2,390,941 (Washington, DC: US Patent Office, 1945).

25 United States Environmental Protection Agency, '2,4,5-T: Position Document 1' (Washington, DC: EPA, 1979), 5. 
formed Agent Orange were, by 1960, a staple of the herbicide economy, reaching end consumers through various blended products. ${ }^{26}$ By 1967, herbicide production had moved well beyond these two herbicides, too, to include newer chemicals that affected plant metabolic functions in different ways. Total herbicide production in 1967 was 348 million pounds (158 million $\mathrm{kg}$ ); of this, 2,4-D accounted for 83.8 million ( 38 million $\mathrm{kg}$ ) (24 per cent) while $2,4,5-\mathrm{T}$ production was 27.2 million (12.3 million kg) (8 per cent). ${ }^{27}$ This herbicide transition expanded from the US to many developing countries in the 1950s and 1960s. Technical experts supported by the US Department of State often introduced herbicides and sprayers in these sites; this impetus was not limited to capitalist countries, either. Soviet agronomists and entomologists advanced similar projects. ${ }^{28}$ By the late 1950s, US federal agencies, including the Forest Service, the Bureau of Land Management and the Department of Defense (DOD), became significant buyers of synthetic herbicides. The US Federal Supply Service published in 1958 the first federal specification for 2,4,5-T herbicides, a recognition that herbicides had entered the mainstream of government purchasing alongside paper clips, diesel fuel, hammers and combat boots. ${ }^{29}$ The following year, Congress amended FIFRA to specifically include language for chemicals acting as a 'plant regulator, defoliant or desiccant', recognising the unusual dual nature of synthetic auxin herbicides. ${ }^{30}$

While writers such as Carson repeatedly linked the rapid growth in pesticide use to a 'chemical war' against nature, the US military's research into herbicides as weapons diminished after 1945, before returning to life in 1959 with the Vietnam conflict. Commercial herbicide research and production grew rapidly, while the US military effectively walled off its tactical herbicide research and proceeded to develop unique formulas separate from the commercial market. While most American research universities conducted research with 2,4,5-T and other pesticides, the US military was committed to a much smaller research program with herbicides at its biological

26 United States Tariff Commission, Synthetic Organic Chemicals: United States Production and Sales, 1958 (Washington, DC: US General Printing Office, 1959), 47. Note that the herbicides sold were typically formulated from technical 2,4,5-T or 2,4-D acid into various esters or salts. The Tariff Commission reports double-count the precursor acid form and the various ester and salt forms used in approved herbicides.

27 United States Department of Agriculture, The Pesticide Review: 1968 (Washington, DC: USDA Agricultural Stabilization and Conservation Service, 1969), 3.

28 Thomas Robertson, 'Cold War landscapes: Towards an environmental history of US development programmes in the 1950s and 1960s', Cold War History 16, no. 4 (2016): 417-41, doi.org/10.1080/14682745.2014.950238. A 1971 survey of Soviet pesticide production and use notes that 2,4-D accounted for most of the herbicides used. See Philip R. Pryde, 'Soviet Pesticides', Environment: Science and Policy for Sustainable Development 13, no. 9 (1971): 19.

29 United States Federal Supply Service, 'Herbicide, 2,4,5-Trichlorophenoxyacetic Acid (2,4,5-T) (Salts and Esters)' (Washington, DC: GSA, 1958).

30 United States Environmental Protection Agency, Legal Compilation: Statutes and Legislative History, Executive Orders, Regulations, Guidelines and Reports (Washington: GPO, 1973), 89. 
and chemical weapons laboratory, Fort Detrick. The unique demands of the tropical terrain in Vietnam and the worsening Cold War situation there prompted this specialised program's unusual growth. ${ }^{31}$

\section{$2,4,5-T$ in the military economy}

While Moore's notion about metabolic 'shifts' is especially useful in theorising the inter-related processes of 2,4,5-T's commercialisation and agroecological changes, it does not easily account for the ways that global political events altered 2,4,5-T's relative military values in the Cold War. The successful Soviet launch of the Sputnik satellite in 1957 prompted President Dwight D. Eisenhower to establish the Defense Advanced Research Projects Agency (DARPA); in turn, DARPA funded the new herbicide research at Detrick. ${ }^{32}$ At the same time, American interest in the mountainous forests covering the Laos-Vietnam border increased sharply due to political and military changes on the ground. Communist leaders in Hanoi had grown anxious in late 1958 that their southern comrades were building a military resistance in the Republic of Vietnam without them. General Secretary Lê Duẩn pushed for expansion of overland supply routes through the mountains to provide weapons as well as oversight. The party passed a resolution in May 1959 creating the 559 Transportation Group to develop what Americans later called the Hồ Chí Minh Trail. This brought instant affirmations of support from the People's Republic of China and the Soviet Union. ${ }^{33}$ That same month, American military personnel began accompanying South Vietnamese military units on missions, and US Special Forces camped near the trail network reported occasional assaults. ${ }^{34}$ The political and military situation in Vietnam continued to deteriorate in 1960-61, so President John F. Kennedy and his South Vietnamese counterpart, President Ngô Đình Diệm, embarked on a deliberate foray using herbicides in counter-insurgency actions. From the first spray tests conducted in August 1961, Kennedy and his military advisors understood that people might interpret the program as a form of chemical warfare. ${ }^{35}$ Despite these concerns, the military web of production for tactical herbicides ramped up, especially with the build-up of US advisors in 1962. That year the DOD

\footnotetext{
31 Environmental lawsuits involving the US Army at Fort Detrick have, like Agent Orange litigation elsewhere, produced richly annotated histories. See United States Army Corps of Engineers, Archives Search Report Findings for Field Testing of 2,4,5-T and Other Herbicides: Fort Detrick (St Louis, MO: USACE, 2012), 4.

32 United States Army Corps of Engineers, Archives Search Report, 8.

33 Lien-Hang T. Nguyen, Hanoi's War: An International History of the War for Peace in Vietnam (Chapel Hill, NC: University of North Carolina Press, 2012), 41-7.

34 Ronald H. Spector, Advice and Support: The Early Years of the United States Army in Vietnam 1941-1960 (New York: Free Press, 1984), 332.

35 The official US Air Force history of Operation RANCH HAND, published in 1982, provides an exceptionally detailed account of these exchanges in 1961. See William A. Buckingham, Operation RANCH HAND: The Air Force and Herbicides in Southeast Asia, 1961-1971 (Washington, DC: USAF, 1982), 11-22. For a more wide-ranging contemporary analysis, see David Zierler, The Invention of Ecocide, 48-66.
} 
sent large quantities of 2,4,5-T to Vietnam via two ships departing an Oakland shipping terminal carrying over 144,000 US gallons $(545,100 \mathrm{~L})$, worth more than US $\$ 2.5$ million. ${ }^{36}$ That order accounted for 12 per cent of total US production of $2,4,5-\mathrm{T}$ that year. ${ }^{37}$

Within this global military economy, tactical herbicides provided one (politically) cheap fix to problems of sending money and soldiers to Vietnam. The herbicide opened up paths of transportation and communication on the ground. It denied vegetation cover for would-be attackers. It enhanced aerial surveillance and made it costly for insurgents to cross these opened areas. As the conflict grew in importance in Washington, the government placed more value on herbicides and other chemicals, especially another naphthalene derivative, napalm, to win the war more quickly and at a lower cost in American lives. ${ }^{38}$ This new military economy for herbicides and other chemicals in turn drove a new set of legal and symbolic processes to produce tactical herbicides that could not also enter the broad webs for commercial herbicides. The DOD issued new military specifications to producers governing production and supply of military herbicides, with printed warnings prohibiting their use in lieu of commercial herbicides, even on military bases. Army researchers at Fort Detrick in 1963 created a purchase description for 'Herbicide Mixture, Orange', which guided chemical companies in producing a new, blended tactical formula. These legal and bureaucratic procedures, more than chemistry, distinguished Agent Orange from near-identical commercial herbicides using a similar 50/50 mixture. The secrecy and controversy about the spraying in the 1960s also helped to wall off this archival record of the tactical herbicide's production and use. ${ }^{39}$

While histories of Agent Orange have followed the rapid expansion and sudden end to the military's procurement and shipping of tactical herbicides, they do not generally consider how this specialised, top-secret flow compared to larger trends of 2,4,5-T production or the pesticide economy in the 1960s. A comparison of production statistics from annual US Tariff Commission reports and DOD records (Figure 1) shows one production bottleneck at the peak of spraying in 1967-68. DOD purchasing agents briefly attempted to control all US production of the herbicide, but they soon reversed course when inventory specialists in Vietnam

\footnotetext{
36 Buckingham, Operation RANCH HAND, 29.

37 This is a rough figure derived from Buckingham's account of the total volume delivered to Vietnam in 1962 (Operation RANCH HAND, 29) and Young's figures for approximate weight per litre of the different herbicide formulations (Agent Orange, 29).

38 Napalm was developed in the Second World War as a gelling agent for incendiary bombs. Harvard researchers developed it from a mixture of aluminum and magnesium salts of naphthenic and palmitic acids. See Robert Neer, Napalm: An American Biography (Cambridge, MA: Harvard University Press, 2013), doi.org/10.4159/ harvard.9780674075450.

39 United States Army, 'Edgewood Arsenal Purchase Description. Herbicide Mixture, Orange' (1963). Described in Young, Agent Orange, 41-2.
} 
reported a build-up of unused stocks. ${ }^{40}$ Also, with respect to 2,4,5-T production, DOD orders in the $1960 \mathrm{~s}$ accounted for less than a third of 2,4,5-T production from 1955 to 1970 (Figure 1). The market context for 2,4,5-T use as a herbicide had changed considerably by the mid-1960s as farmers and companies had moved on to cheaper chemicals with more selective functions on targeted weeds. The USDA's 1971 Pesticide Review charted this peak of 2,4,5-T production from 42 million pounds (19 million $\mathrm{kg}$ ) in 1968 to 11.6 million (5.3 million $\mathrm{kg}$ ) in 1969 and 14.5 million (6.58 million $\mathrm{kg}$ ) in 1970. Meanwhile, production of other herbicides in this same chemical category (cyclic synthetic organic herbicides) increased by more than 600 per cent in the same period. ${ }^{41}$

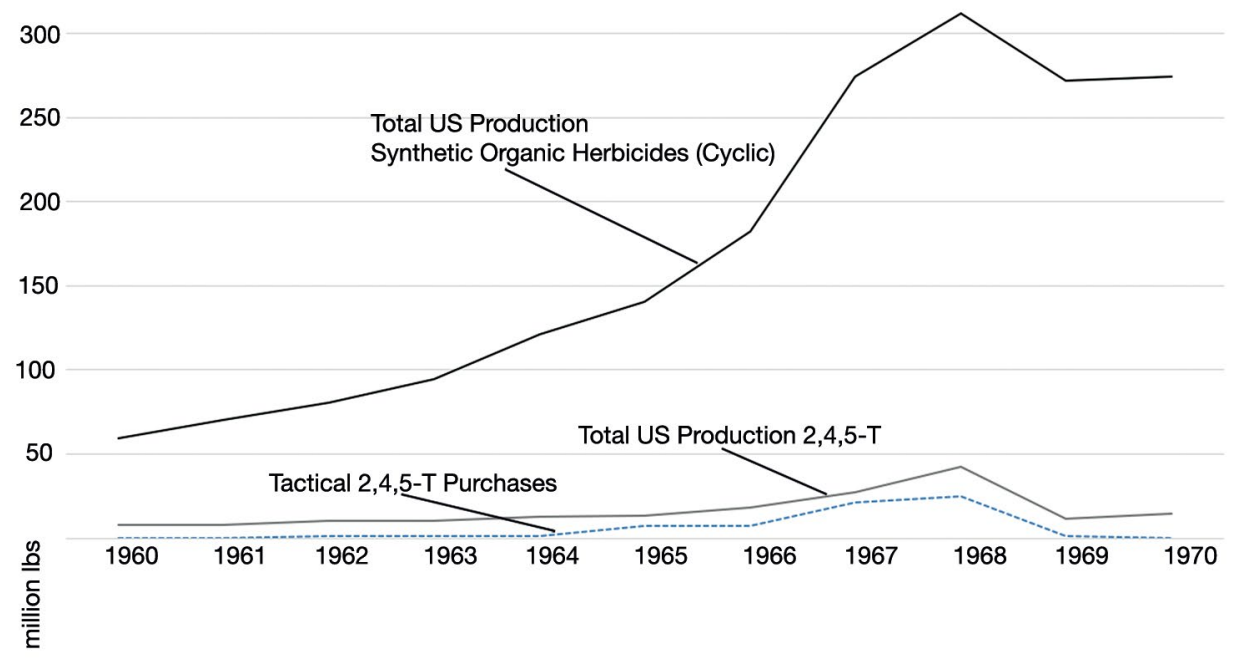

Figure 1: Graph comparing DOD purchases of tactical 2,4,5-T with total US production of 2,4,5-T and total US production of all synthetic organic herbicides (cyclic)

Sources: US Tariff Commission Reports, 1960-70. DOD Procurement: Young, Agent Orange, 173-5. Graph compiled by author.

Considering the value of 2,4,5-T in relation to a rapidly expanding Pandora's box of pesticides, this data suggests that in the 1960s the number of competing herbicides, even just those synthetic ones derived from naphthalene and benzene, had rapidly expanded. The volume of substitutes for 2,4,5-T grew more than 600 per cent. (Commercial demand for the other herbicide in Agent Orange, 2,4-D, continued to grow in this period as well, and use continues to the present day.) Finally, the

40 Dorothy Craig, Use of Herbicides in Southeast Asia (San Antonio, TX: San Antonio Air Logistics Center, 1975), $19-22$.

41 United States Department of Agriculture, Pesticide Review: 1970 (Washington, DC: USDA Agricultural Stabilization and Conservation Service, 1971), 18. After 1970, in part due to the partial ban, the pesticide review no longer listed 2,4,5-T as a separate line item. However, production continued into the 1970 s as its use was still allowed for non-food applications. 
last year for which 2,4,5-T production was singled out in the Tariff Commission reports, 1970, is important as it suggests that even after the US military ceased purchasing 2,4,5-T for Agent Orange, there was an uptick in domestic demand. Ranchers continuing using the herbicide until 1979 and utility crews clearing rights of way on roads and power lines used the herbicide until it was fully banned in 1985.42 Thus, even as the US Air Force and the DOD worked out the highly controversial disposal of Agent Orange stocks in 1977 and responded to various court cases, power companies and highway grounds crews continued spraying 2,4,5-T domestically, contributing to dioxin's global background levels.

\section{Transport and 'drift' in the war zone}

As the introduction describing the 10th Chemical Platoon's daily operation suggests, 2,4,5-T was just one of many chemicals, tactical and non-tactical, moving through combat zones, bodies and ecosystems in Vietnam. While at the macroeconomic level, consumer demand and relative values of 2,4,5-T and herbicide substitutes explained its geographic dispersion to crops, forests and rights of way, in Thừa Thiên Huế Province in Vietnam (Figure 2), the herbicide flowed according to a different logic, but also in geographically distinctive ways. Returning to Moore's notion of 'Cheap Nature', the tactical herbicide Agent Orange fulfilled a similar logic in Vietnam, but directed into the economy of combat. Instead of boosting crop or forest production, its primary value rested in eliminating them as resources for communist forces. A DARPA contractor in 1963 listed the following uses for 2,4,5-T in a war zone: eliminating vegetation cover, roadside clearance, boundary demarcation; vegetation control along base perimeters; destroying crops; and, finally, eliminating aquatic weeds, floating mats of water hyacinth that impeded river boats. ${ }^{43}$

While these tactical uses of the weaponised 2,4,5-T suggest the ease with which Agent Orange entered Vietnamese ecosystems through intensive aerial spraying, records associated with military herbicide spraying suggest a fairly concerted effort between the United States and South Vietnam to confine Agent Orange and the 'rainbow herbicides' (Agents Orange, White and Blue) to specific corridors and combat sites. Figure 2 shows a composite of three georeferenced sets of war records designed to show how the spraying of Agent Orange (represented as orange spray runs below) fit within the war zones of Thừa Thiên Huế Province. Agent Orange spray runs were generally limited to the mountainous western region of the province, largely controlled by communist forces by 1967. Like the clusters of red points

42 United States Environmental Protection Agency, 'Decision and Emergency Stop Order Suspending Registrations for the Forest, Rights-of-Way, and Pasture Uses of 2,4,5-Trochlorophenoxyacetic Acid $(2,4,5-\mathrm{T})^{\text {' }}$ (Washington, DC: USEPA Office of Pesticide Programs, 1979). On the $1985 \mathrm{ban}$, see 'All uses of 2,4,5-T and silvex pesticides banned', Chemical Engineering News 63, no. 12 (1985): 6.

43 Young, Agent Orange, 60-3. 
representing US aerial bombing missions, the spraying was especially concentrated in the A Sầu Valley and at entry points where communist trails (yellow arrows) entered the province from Laos. FSB Bastogne, the firebase sprayed by the 10th Chemical Platoon in 1970, was the American military's last stronghold on the one paved road running west from the coast to the A Sầu Valley.

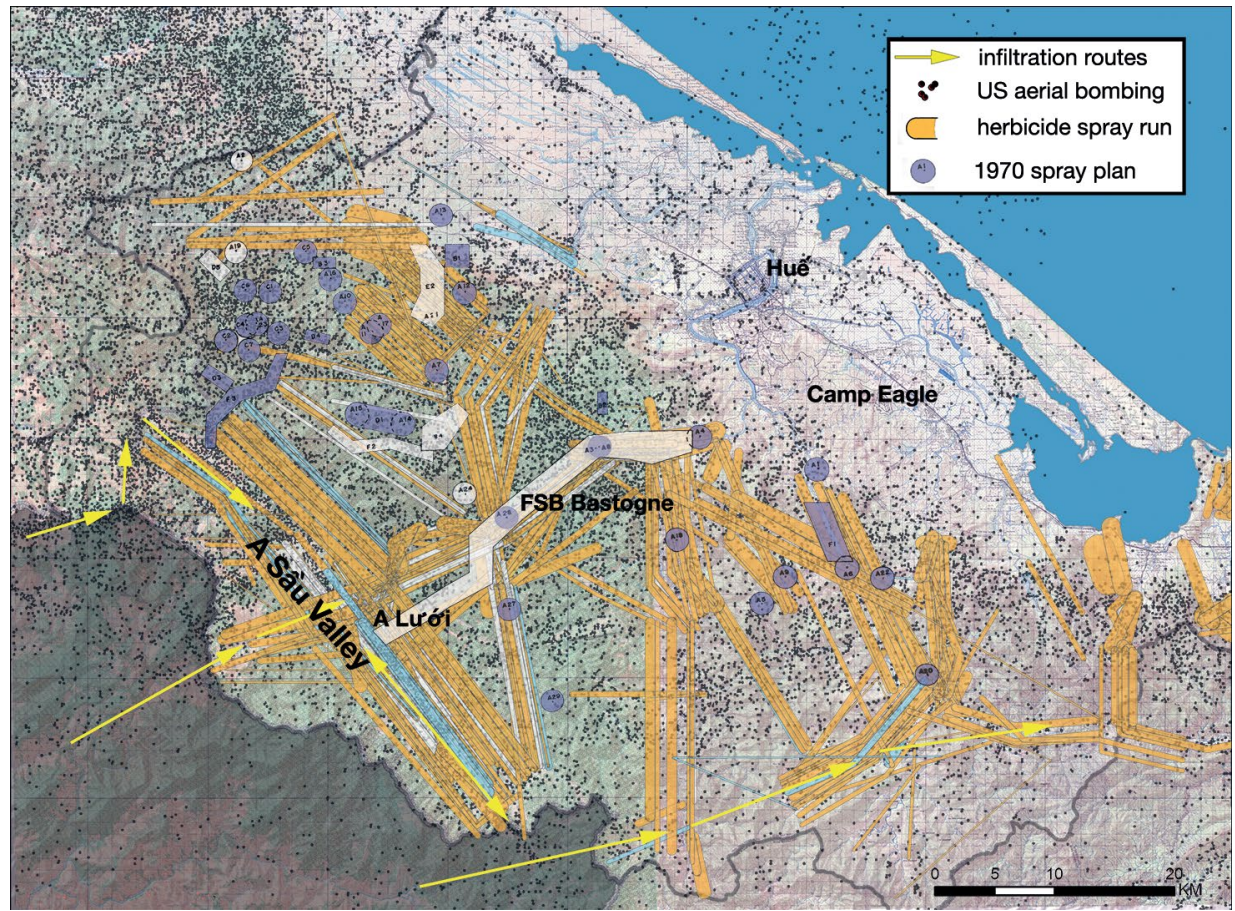

Figure 2: Spray runs, 1970 spray areas and bombing in Thừa Thiên Huế Province

Sources: Map by author. This image is a simplified composite of four historical-geographical sources: (1) a US bombing database; (2) records of herbicide flying missions; (3) a 1970 provincial military record for proposed spray sites; and (4) described infiltration routes. Sources are (1) United States Air Force, 'THOR: Theater History of Operations Reports', afri.au.af.mil/thor/\#.WV4KJdOGPyt, accessed 7 July 2017; (2) spray runs digitised by author, derived from source data in United States Air Force, 'HERBS Tape: Defoliation Missions in South Vietnam, 1965-71' (Washington, DC: USAF, 1985), www. nal.usda.gov/exhibits/speccoll/items/show/1257, accessed 7 July 2017; (3 and 4) source digitised and georeferenced by author, derived from paper record 'Herbicide Operations Project 1/2/2/70', Records Pertaining to Herbicide Operations, Assistant Chief of Staff for Operations (G3) Advisor, MACV First Regional Assistance Command (FRAC), RG 472, National Archives-College Park (NARA2).

Even in this specialised war herbicide economy with articulated target zones and depopulated areas, problems of spray drift and accidental destruction of non-combatant or 'friendly' crops highlight the ecological and political limitations of herbicide operations. A US military review of the herbicide program noted that thousands of farmers petitioned the South Vietnamese military regarding damage to crops. The highly volatile form of 2,4,5-T used in Agent Orange tended to drift several kilometres with the wind. Another American study noted that failures 
to compensate farmers also posed deep political and tactical problems. Some disgruntled farmers joined the insurgents, and American attempts to reimburse farmers presented opportunities for widespread corruption as the South Vietnamese Government lacked sufficient oversight to verify crop damage claims. ${ }^{44}$

In both strategic and economic senses, problems with Agent Orange's physical drift into 'friendly' fields or onto persons pointed to deeper, underlying problems with the logic of using 2,4,5-T as a tactical herbicide. Pilots could not tease out 'friendly' from 'enemy' persons in the large spray areas, and sprays often drifted onto US soldiers. Given increased political resistance in South Vietnam and emerging scientific reports in 1969 on dioxin's alleged effects on foetal development, the US military faced an increasingly steep hill to climb in justifying spraying even in war-zone targets such as the A Sầu Valley. The following excerpt from a planning document of 1970 illustrates how far the military's logic of mitigating damage to civilians had been stretched. The report explained:

Intelligence estimates indicate approximately five regiments or a total of 10,000 NVA/ VC troops are located within the target area. No friendly or pro GVN inhabitants are known to be living in the area and the Montagnard population is estimated to be approximately 9600 . The resultant native population density of the entire area is less than four individuals per square kilometer. ${ }^{45}$

This strange mathematics, averaging the indigenous population across the area of the entire spray run, was a grim attempt to distract from the possibility that concentrated villages of Montagnard people and their crops were squarely in the middle of spray paths that might expose them to potentially teratogenic dioxin. This diminished valuing of highlander lives, not to mention enemy forces, drew increasingly severe responses from South Vietnamese allies who worried that communist propaganda about 'poison sprays' might contain an element of truth. Many mountain peoples had become linked with the trail system and the communist war effort, too. In the A Sầu Valley, communist political and military units had since the late 1940s supported the local economy and recruited many highlander youths. Some received advanced officer training, and many highland villages supplied food as well as labour for the trails and rest areas. ${ }^{46}$

44 Drawing from the US military's Herbicide Policy Review and other key documents, Martini provides an excellent synopsis of this debate over drift. See Martini, Agent Orange, 77-83.

45 'Herbicide Operations Project 1/2/2/70', Records Pertaining to Herbicide Operations, Assistant Chief of Staff for Operations (G3) Advisor, MACV First Regional Assistance Command (FRAC), RG 472, NARA2.

46 Local party histories of these mountainous districts note significant participation in both political and military agendas by the ethnic minorities in the highlands. Many descendants of these highlanders continue to serve in regional and national government posts in the present. For histories of Montagnard participation in Thừa Thiên Huế Province, see Ban Chấp Hanh Đảng Bộ Huyện Nam Đông, Lịch Sử Đảng Bộ Huyện Nam Đông (1945-2000) [History of Nam Đông Party Unit, 1945-2000] (Hà Nội: NXB Chính Trị Quốc Gia, 2003), 48-54; and on ethnic minority participation in the A Sầu Valley, see Đảng Ủy Ban Chỉ Huy Quân Sự Huyện A Lưới, Lịch Sư Lực Luợng Vũ Trang Nhân Dân Huyện A Luới (1945-2010) [History of Popular Armed Forces in A Lưới District] (Hà Nội: NXB Quân Đội Nhân Dân, 2011). 
In such heavily bombed areas as the A Sầu Valley, much of the herbicide not absorbed in plant leaves flowed into the circular, muddy ponds left by thousands of bomb craters. With the monsoon downpours, residues of the oily herbicides overflowed from these craters into the A Sap River, which brought water to the valley's rice paddies and villages. In the muddy pools of bomb craters, while the herbicide degraded quickly from sunlight and oxidation, the heavier dioxin molecules settled in the sediment. The A Lưới area (Figure 3) was especially targeted for spraying and bombing during two peaks of fighting in 1966 and 1969-70. The underlying 1967 satellite image in Figure 3 shows the white dots of bomb craters running in lines of individual runs roughly a kilometre long. ${ }^{47}$ Visible from space, these craters formed a patchwork of ponds trapping dioxin in individual spots.

Even for the herbicide that reached its vegetation targets and did the desired work, it also produced unanticipated results and tactical problems with respect to ecological responses. The spray missions depicted in Figure 3 show runs of three different herbicides; the location of each in this valley suggests slightly different military concerns about the targeted plants below. The A Sap River running through the A Sầu Valley was a vital source of fresh water for rice, and strips of the herbicide Agent Blue (coloured blue) reflect the intent to destroy these crops. Additional runs of Agent White (coloured white) along the river's course and fringing it for a few kilometres on either side suggest that herbicide planners were intent on killing a wide spectrum of trees and broadleaf crops for longer durations. Agent White contained a different synthetic hormone, picloram, that, while more expensive than 2,4,5-T, was more effective at eliminating vegetation more permanently than Agent Orange. ${ }^{48}$ Agent Orange was clustered along steeper slopes fringing the valley, areas covered in forest or non-rice staples such as cassava. When the autumn-winter rains hit, these defoliated (and napalmed) forests on the higher slopes tumbled down in mudslides, clogging and flooding the river valley.

\footnotetext{
47 One additional geographic layer was added in this image, the CORONA satellite image DS1045-1069DA081, 29 January 1968, courtesy of United States Geological Service, lta.cr.usgs.gov, accessed 17 November 2017.

48 Ecologists in particular pointed to picloram in Agent White as a more problematic military herbicide for its persistence. It rendered soils unproductive far longer than Agent Orange. For a detailed study on Agent White, see Leif Fredrickson, 'From Ecocide to Eco-ally: Picloram, Herbicidal Warfare, and Invasive Species, 1963-2005', Global Environment 7, no. 1 (2014): 172-217, doi.org/10.3197/197337314x13927191904961. Agent Blue was an arsenical herbicide and used especially for killing rice crops. See United States Army, Field Manual 3-3: Tactical Employment of Herbicides (Washington, DC: US Army, 1971).
} 


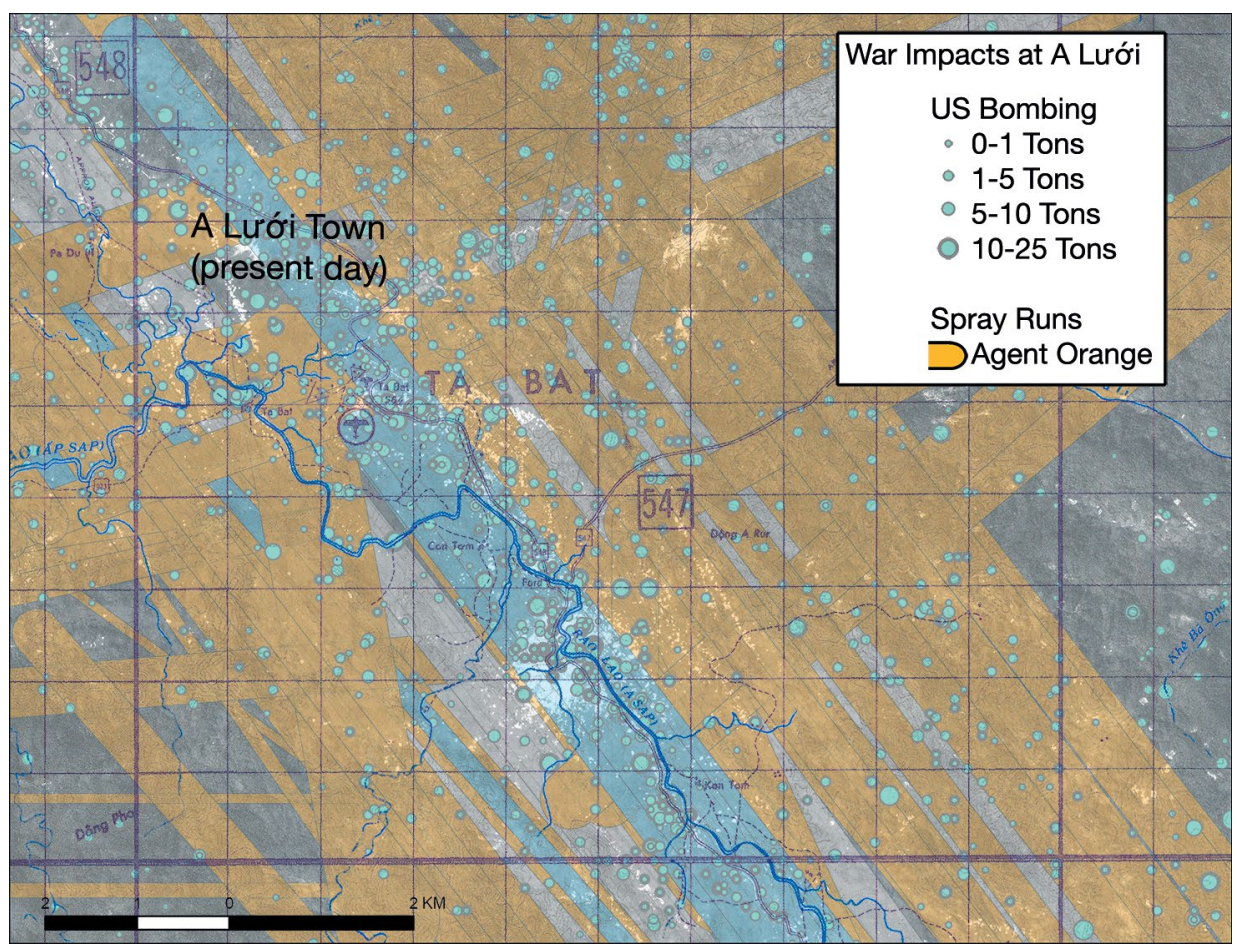

Figure 3: Herbicide spraying and bombing in A Lưới

Sources: See Figure 2 sources. Map by author.

Whereas the relationship of the commercial herbicide to the farm economy permitted certain boosts in profits as a labour-saving technology, the herbicide's drift in Vietnam brought about unexpected ecological and tactical consequences. One result of defoliating broadleaf plants such as rainforest trees was the opening of slopes to the widespread expansion of tall grasses. An American visitor to spray zones in 1969 noted a variety of grasses growing 2-3 metres in height. One of the most pernicious was an invasive grass that had hitchhiked from American bases in Guam: elephant grass (Pennisetum purpureum). This grass, along with various species of cane and the food crop sorghum, thrived in Vietnam's defoliated hills. The intensive and repeated sprayings of Agent Orange across large swathes of hills produced in effect a new ecotone similar in some respects to pasture lands elsewhere. Communist troops adapted to the dense grass and cane, forging new paths and adding new camouflage. ${ }^{49}$

Aside from routine North Vietnamese radio broadcasts about the 'poisonous sprays', soldier experiences and imagery describing these defoliated landscapes became a significant element of war stories and protest literature. Veterans interviewed by

49 Robert A. Darrow, 'Report of Trip to Republic of Vietnam, 15 August-2 September 1969', Alvin Young Collection, USDA National Agricultural Library, nal.usda.gov/exhibits/speccoll/files/original/f994332e7ad90bc 
the author near Huế repeatedly touched on the challenges that spraying posed for camouflage. One individual who served in the National Liberation Front described how American helicopters dropped 'gasoline bombs' ('bulk flame drops') that singed hills black while suffocating anyone hiding underground. After these runs, he continued using the same routes but changed his leafy green camoflauge to blackened char, or later to grasses, to mimic these changes on the ground. ${ }^{50}$ A North Vietnamese journalist travelling these post-spray hillsides in 1967 used the ruined setting to evoke a familiar strain of anti-war sentiment:

We march in the desolate gray of the forest. Around us, giant trees, their foliage stripped by poison chemicals, thrust their stark branches into the sky. Their ghostly silhouettes march across a low and cloudy sky, heavy like a soaked quilt ... here, on these mountains once green with heavy growth, such a rage against nature seems insane. One finds himself asking: 'But what do they want?' Is it possible that the superforts [B-52s] fly all the way from Guam, so far through the air, just to change the color of this forest? ${ }^{51}$

While the author confuses the high-altitude B-52s involved in saturation bombing with the low-altitude, slow-moving sprayer planes (C-123s), the above passage reinforced the increasingly popular Agent Orange 'ecocide' story. By 1969, photographs of dead trees and grey hillsides began appearing regularly in American anti-war newspapers and pamphlets and, in 1970, one young American war protester, Barry Weisberg, published the first American book on the subject. Ecocide in Indochina: The Ecology of War popularised the term 'ecocide' and advanced the older, North Vietnamese argument that the military herbicide program was, in moral terms, a war crime..$^{52}$

\section{Narrative and metabolic conflict: Dioxin in the 'ecocide' story and its 'fate' in Vietnam}

While the herbicide's drift in Vietnam was one negative aspect of its metabolic functions in the war zone, since then, the drift of its contaminant dioxin has demonstrated the ability to not only cross the social-natural divide but also to cross multiple spaces and timescapes. After the US ceased spraying and as the partial ban on 2,4,5-T took effect, the 'ecocide' story about 2,4,5-T gave way to a new variant, a persistent poison story, while knowledge of dioxin's metabolic effects remained clouded in debate. The US refused to open diplomatic ties with the Socialist

50 Author interview with Mr Dan, 2 February 2012, Thủy Phương Commune, Thừa Thiên Huế Province. Also like many other bô dọi (infantry) soldiers who fought in these areas, Mr Dan reported that he could not have children after he and his wife gave birth to a severely disabled daughter in 1984 . He believed that her ailments were directly related to his exposure to dioxin.

51 Trần Mai Nam, The Narrow Strip of Land (Hanoi: Foreign Languages Publishing House, 1969), 9-10.

52 Barry Weisberg, Ecocide in Indochina: The Ecology of War (New York: Harper \& Row, 1970). 
Republic of Vietnam after the war, thwarting opportunities for collaborative, onsite research. During this frozen period in US-Vietnamese relations until 1994, stories about dioxin's toxicity remained a staple in Vietnamese claims for the US to pay reparations for damages as a precondition to the normalisation of diplomatic ties. To drive home the point, the Vietnamese Government used the former US Embassy in Hồ Chí Minh City to house the American War Crimes Museum where several rows of jars containing stillborn, severely malformed babies from the Sài Gòn Maternity Hospital were on display. This macabre display was presented as evidence of the effects of the 'Orange poison' (chất độc mầu da cam).${ }^{53}$ While Vietnamese tour groups, school classes and foreign visitors passed through the museum, Vietnamese scientific research on dioxin's potential health impacts remained highly classified. Meanwhile, in the US, contentious scientific studies were unable to fully resolve questions about dioxin's properties as a teratogen or carcinogen. Congress in 1970 ordered the National Academy of Sciences to conduct a comprehensive study on teratogenic effects of 2,4,5-T and dioxin. The study, released in 1974, pointed to extensive ecological damage but could not show extensive linkages between dioxin and various attributed birth deformities and illnesses. ${ }^{54}$

These Vietnamese public displays and the highly publicised US debates helped elevate the controversial dioxin story into an elite circle of toxic disaster narratives; however, public understanding of either the herbicide 2,4,5-T or the movement of dioxin often ran counter to the research. New research in the 1990s showed that large areas of former spray zones contained levels of dioxin comparable to background levels (0-5 parts per trillion (ppt)) in industrialised countries. Meanwhile, other findings showed that dioxin believed to have settled into pond sediments had instead become highly mobile in the food chain, travelling with animals to markets and with humans across Vietnam and beyond. Much of this new research stemmed from a late 1990s collaboration between Canadian and Vietnamese researchers in the A Sầu Valley. A three-year study generated comprehensive analysis of soils, animal tissue, human blood samples and human breast milk with state-of-the-art surveys in Canadian laboratories. ${ }^{55}$ Soil tests conducted across the valley confirmed that dioxin sprayed from the aircraft had dissipated from non-detectable to 5 ppt. Sites with remaining elevated concentrations of dioxin were concentrated around former American Special Forces bases in the valley. At the longest-occupied base, A Shau, an area near the former American compound that had been excavated for

53 The author visited the museum in 1993 before the US re-established diplomatic ties and the museum was closed. Many of the exhibits have since 1994 been relocated to the city's War Remnants Museum; only a few of the foetuses can now be seen in the new museum.

54 Committee on the Effects of Herbicides in Vietnam, The Effects of Herbicides in South Vietnam, Part A (Washington, DC: National Academy of Sciences, 1974). See also Deborah Shapley, 'Herbicides: Academy Finds Damage in Vietnam after a Fight of Its Own', Science 183, no. 4130 (1974): 1177-80.

55 L. Wayne Dwernychuk, Hoang Dinh Cau, Christopher T. Hatfield, Thomas G. Boivina, Tran Manh Hung, Phung Tri Dung and Nguyen Dinh Thai, 'Dioxin reservoirs in southern Viet Nam-A legacy of Agent Orange', Chemosphere 47 (2002): 117-37, doi.org/10.1016/S0045-6535(01)00300-9. 
aquaculture ponds, showed dioxin levels in the soil at 300-400 ppt. The joint study recommended focusing attention on these 'dioxin reservoirs' where the contaminant was likely concentrated as a result of industrial spills. ${ }^{56}$

While the dioxin may have dissipated from the soils of affected spray runs, the group identified a more troubling finding with respect to its mobility through animal tissue and fat. As a heavy molecule, it quickly settled in river and pond sediments after the war; however, disturbances_ — particularly the daily feeding of ducks and fish—released the dioxin into the water, where animals ingested it. Dioxin bioaccumulates in fat like other hormone-disrupting chemicals, so the team checked dioxin levels in A Shau's ducks, fish and other animal products. They detected high concentrations of dioxin: from 80 to $95 \mathrm{ppt}$ in the fat and livers of ducks and fish. Humans eating the ducks and fish then ingested dioxin with the animals' fatty tissue or organs. Pregnant women, most of them born after the war ended, passed dioxin through fatty acids to foetuses and, later, through fat-rich breast milk to infants. Samples of breast milk collected near the hotspot at A Shau showed levels ranging from 5 to $20 \mathrm{ppt}$; estimates of early childhood exposures before age three ranged from 20 to almost $100 \mathrm{ppt}^{57}$ While these findings have helped to allay general fears in Vietnam about possible pathways of exposure, they also raise persistent public fears of possible dioxin contamination in present-day animal products produced near former hotspots.

Besides concerns about dioxin's potential effects within the bodies of mothers and infants, new research in medical genetics suggests that dioxin exposures may even leave further-reaching, multi-generational signatures in the coding of DNA. Current studies focused on dioxin's effects on DNA in Vietnam suggest a possible association between a parent's past environmental exposures and, via a process called DNA methylation, the intergenerational transfer of this DNA to children. Researchers since the 1960s have long observed through malformed foetuses a teratogenic effect of dioxin exposure. This new wave of studies in epigenetics suggests that past dioxin exposures may leave biomarkers in offspring. ${ }^{58}$ As with the hotspot study at the A Shau base, this study found no evidence that persons at present living in historically sprayed zones showed any effects of exposure, whether through above-background dioxin levels in tissues or in their DNA. Rather, the study suggested that the likelihood of certain DNA markers associated with dioxin exposure had more to do with a subject's parents' initial exposure to DNA. Parents who worked in spray zones during the war and had been directly sprayed showed a greater likelihood of presenting a set of common genetic markers. Even as dioxin

56 Dwernychuk et al., 'Dioxin reservoirs', 121.

57 Dwernychuk et al., 'Dioxin reservoirs', 132.

58 Christina Giuliani, David Biggs, Nguyen Thanh Tin, Elena Marasco, Sara De Fanti, Paolo Garagnani, Le Phan Minh Triet, Nguyen Viet Nhan, Donata Luiselli and Giovanni Romeo, 'Past environmental exposure to dioxin is associated with DNA methylation changes of CYP1A1 and IGF2 genes in present day Vietnamese population' (currently under review). This area of genetics research is still very young, and it should be noted that the existence of biomarkers still does not confirm a link to attributed illnesses. 
levels dissipate to near-zero levels, a 'death' phase in this history of the molecule, dioxin may have an 'afterlife' in these metabolic 'echoes' of rewired DNA that may persist for generations and later be found to have associations with various illnesses. Given estimates of Vietnamese exposed to 2,4,5-T spraying on the order of 1-2 million persons, these epigenetic signatures may present in significant portions of the population for generations to come. Further tests of American veterans and their offspring, as well as the descendants of commercial pesticide applicators, might show a common signature in their DNA, too.

\section{Conclusion}

Travelling with these dioxin molecules from their synthetic origin to their envelopment in 2,4,5-T herbicides, their uptake at hotspots and their epigenetic afterlives in DNA, this metabolic approach challenges the notion that individuals, like pollution sites, are static entities fixed in specific temporal boundaries. Epigenetics research and genomic studies are showing increasingly that DNA, the building block of life and individual human traits, continues to morph and shift in response to external stimuli. As a synthetic molecule, dioxin presents a challenge to ethicists and historians as daunting as atmospheric carbon and endocrine disruptors. As an historical subject, the molecule is mute, exerting no intent of its own. Instead one must follow its metabolic effectsof 2,4,5-T on plants and of dioxin on animals and humans. Despite increased awareness of these metabolic events in veterans and the ecosystems of Vietnam, fitting this more interconnected perspective on dioxin with established individual suffering or moral narratives means challenging to some extent the nature of popularly accepted Agent Orange stories. Even as researchers and soil scientists document near-complete degradation of dioxin after 50 years in many former spray zones, these older 'poison' stories associated with past spray sites often return. The metabolic terms for dioxin's release and subsequent disappearance (or localised persistence) are more nuanced, more complex than most stories will allow.

To put this problem of the pollution narrative and alleged 'sufferers' in more concrete terms, one may consider the plight of people now living near the dioxin hotspot of the former A Shau base. In 2015, the author visited the site and nearby Đồng Sơn Commune with a group of American students and a Vietnamese ecologist. ${ }^{59}$ The visit,

59 The ecologist Dr Phung Tưu Bôi is nationally and internationally known for his work in the A Sầu Valley. In 2007, the New York Times featured his development of the 'green fence' approach to keep village cattle from grazing around the hotspot area. See Christie Aschwanden, 'Through the Forest, a Clearer View of the Needs of a People', New York Times, 18 September 2007, www.nytimes.com/2007/09/18/science/18prof.html, accessed 12 July 2017. The environmental activist Susan Hammond also describes elements of the A Shau site as well as the problem of disentangling the Agent Orange disaster narrative from specific sites like A Shau and the nearby commune. See Susan Hammond, 'Redefining Agent Orange, Mitigating its Impacts', in Interactions with a Violent Past: Reading Post-Conflict Landscapes in Cambodia, Laos and Vietnam, ed. Vatthana Pholsena and Oliver Tappe (Singapore: NUS Press, 2013), 186-207. 
coordinated by an office in A Lưới District, featured stops at the former runway (Figure 4) as well as a visit to the hotspot site at the fringe of the former runway with a ring of thorny trees surrounding the most contaminated zone. The tour ended at the commune meeting hall. Guides pointed to a small infirmary funded by foreign and government contributions, and the chairman of the commune presented the author with a gift of textiles made by the $\mathrm{Ta} \mathrm{Oi}$ indigenous people, who were the historic occupants in this part of the valley. The chairman was a member of this group, as were roughly half the people in the commune.

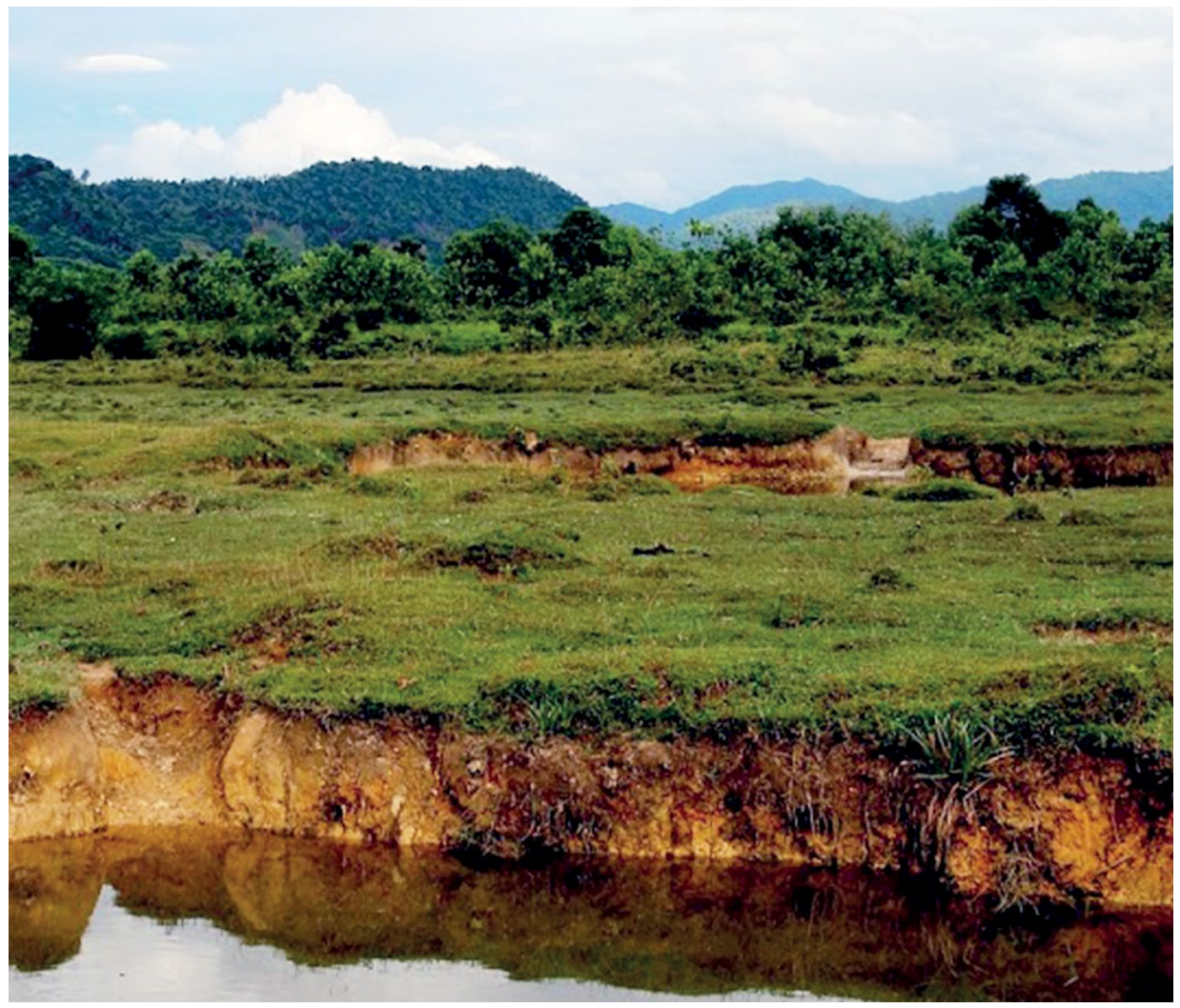

Figure 4: Former A Shau runway with bomb craters

The foreground shows a thin layer of grass covering the remnants of the American Special Forces base abandoned in 1966. The trees in the distance were planted to screen off the dioxin hotspot.

Source: The author.

In the chairman's short welcome speech, he very quickly got to the point about the Agent Orange/war legacy narrative, and more specifically the hotspot story that had drawn the group there. Pointing to the infirmary, he said that what the commune did not need were more scientists and experts coming to draw people's blood and take it away to write their studies. They had a clear enough knowledge, he said, about hotspot locations and how dioxin moved through the food chain. 
The problem that he identified as most vital to the commune's future development concerned affordable or free tests that people could perform to confirm that their land, their animals or perhaps their DNA were 'clean'. He implored the author, the ecologist and the students to develop technologies to effectively map dioxin's presence and absence so that people could work, live and build livelihoods outside any 'hot' zones. Farmers in the commune, he stated, despite general assurances from researchers of background traces of dioxin along the valley floor, continued to encounter discrimination at urban markets when buyers asked their village of origin. The chairman's speech illustrated a particular struggle for those generally not affected by historical encounters with dioxin but who nevertheless continue to suffer under the weight of dioxin history and the Agent Orange stories. Preliminary results in epigenetic research suggest new hope for descendants of the war generation, Vietnamese and American, who even if they suffer no associated illnesses may be curious about their own genomes.

Metabolic history and the metaphor of drift present a path for more stories about environments, from toxic sites to human bodies, where there is neither a static victim or site nor a morally good or bad 'subject'. Dioxin, like many environmental agents and phenomena, lacks intent. Langston concludes in her study of endocrine disruptors that 'science alone cannot solve our chemical problems' and that policymaking communities, no matter how responsible to their constituents, are slow to catch up with changing scientific understandings of toxicity. ${ }^{60}$ In Đồng Sơn Commune, the chairman declared that the village was finished with scientists; and even though knowledge of the hotspot had attracted some press attention, there was no hint of any state-of-the-art dioxin remediation project coming to one of the poorest communes in the valley. Instead, he and his neighbours urged the group to identify and develop 'clean' (sach) spaces in the village and the valley. For those worried about whether their parents may have passed down dioxin-affected genes, he hoped that researchers in the future would develop (cheap) tests to check genetic markers. As the student group toured the former airstrip, guides from A Lưới District's tourism office even wondered if rehabilitating the old American base as a dual war tourism/dioxin education centre might help spur the village economy. The A Shau hotspot and fears of contamination had prevented people from occupying the former base, while most former American sites in Vietnam are now unrecognisable, covered under layers of tree plantations and industrial parks.

No amount of money, technological fixes or environmental regulations will ever fully resolve the human, environmental and health costs associated with Agent Orange, 2,4,5-T and dioxin; however, greater attention to the kinds of environmental stories that we tell may in time contribute to a more long-term project, reconciling human histories with these complex, multi-scalar phenomena. The outlook of the

60 Langston, Toxic Bodies, 159. 
commune chairman and residents of Đồng Sơn is perhaps more useful to students and policymakers than a moral framework focused on perpetrators and victims. For people in places like Đồng Sơn, the most useful stories of pollution are those that aid their safe navigation through a complex space of potentially hazardous toxic molecules as well as more common pathogens. Such stories, like the hopedfor tests, allow their audiences some measures of choice and agency. They know, through work and travel, that the lands where they live are not static, nor are they permanently damaged. Just as dioxin molecules drift, the lands, bodies and DNA that they contact are also in motion. Such dynamic stories may lack historical permanence as the categories of victims, polluters and toxic spaces change. 'Drift' as a metaphor suggests that many environmental events are not bound to a single scale, nation of origin or timescale-thus, it challenges the temporal and spatial frameworks of a story. Metabolic histories built around single chemicals moving through multiple webs may draw criticism for their distributed causal arguments and diluted notions of agency, but they can serve an important revisionist aim of pointing readers to less singular moral frameworks. The metabolic history of dioxin, for example, opens up new, more ambivalent approaches to agency that better suit the complex workings of toxic waste plumes and atmospheric $\mathrm{CO}_{2}$ in the dog days of the Anthropocene. The Agent Orange part of dioxin's story is exceptional in the ways that it and its detailed archives were produced. The abundance of sources describing its development obscures the comparatively global history of 2,4,5-T as a commercial herbicide. By following dioxin's drift across the spectrum of commercial and military herbicide formulas as well as its spectral afterlife in soils and bodies, we can in some senses recalibrate environmental histories that are often overwhelmed by powerful, yet constraining, moral tales. 
This text is taken from International Review of Environmental History, Volume 4, Issue 1, 2018, edited by James Beattie, published 2018 by ANU Press, The Australian National University, Canberra, Australia.

doi.org/10.22459/IREH.04.01.2018.03 